\title{
Development and Optimization of A Non-traditional Extraction Process of Yellow Colorant from Safflower Petals as A Natural Colorant
}

\author{
Martina Megally $^{1}$, N.S. Elshemy ${ }^{2 *}$, K.Haggag ${ }^{2}$, A.I. Hashem ${ }^{1}$ \\ ${ }^{1}$ Chemistry Department, Faculty of Science, Ain Shams University, Cairo, Egypt. \\ ${ }^{2}$ Textile Research Division, National Research Centre, Cairo, Egypt.
}

\begin{abstract}
$\mathbf{Y}$ ELLOW colorant was extracted from safflower petals through grinding, sifting, washing, filtering and drying. The Safflower petals were submitted to innovative extraction using microwave irradiation and under a variety of conditions. Variables studies including safflower concentration, duration of extraction, extracted dye bath $\mathrm{pH}$ and temperature to optimize the extraction condition. The effects of dye concentration, dye path $\mathrm{pH}$, colorant temperature, colorant time and liquor ratio, were studied in terms of dye uptake and shade. Conditional changes in the innovatively extracted colorant and dyeing process vis-à-vis those of traditional extraction and dyeing were presented. The obtained results showed that the innovative extraction as well as dyeing process using the microwave irradiation consumes less time and energy when compared with the traditional technique. The results indicate further that current extraction colorant using the microwave or traditional heating brings into focus yellow colorant, which induces excellent overall color fastness when applied as a colorant in the dyeing of different fabrics. The analysis of absorption mechanism suggested that the hydrogen bonding and electrostatic interactions operating between Safflower yellow colorant and different fabrics lead to Freundlich absorption, though other interactions such as hydrophobic interaction and van der Waals forces contribute to Nernst partition adsorption. Freundlich absorption had a greater contribution to total adsorption of yellow colorant on wool fabric, whereas partition adsorption imparted greater influence to colorant adsorption on silk and wool/polyester blend fabric. The pseudo-second-order model describes appropriately the dyeing process of wool, silk and wool/polyester blend fabric based on safflower yellow colorant materials. The thermodynamic parameters of dye absorption showed a significant difference. The absorption affinity $\left(-\Delta \mu^{\circ}\right)$ of extracted safflower yellow dye on wool, silk as well as wool/polyester blend fabric indicated that the absorption is a spontaneous and exothermic process. So, safflower yellow colorant could be a good candidate as a natural green dye.
\end{abstract}

Keywords: Safflowers, Natural dyes, Microwave, Wool, Silk, Dyeing isotherm, Dye Kinetic.

\section{Introduction}

Textile and Clothing fabrics industry is one of the major and oldest industries present in the world [1-2]. This industry doesn't need special skills, which in turn plays a major role in providing employment in poor countries. Therefore, it plays a vital role in the increase of total local product value of these countries [3]. Since prehistoric time, natural dyes are known for their use in the coloring of food substrate, leather; wood, as well as, natural fibers. Recently, the utilization of non-toxic and eco-friendly natural dyes to coloring textiles has become an important matter to increase environmental awareness and to avert some hazardous of synthetic dyes. However, the utilization of natural dyes for the textiles coloration has mainly been confined to verbatim, small-scale exporters, and producers dealing with high valued eco-friendly textile production and sales [4-6].

Textile industries are always in continuous searching for new and alternative technologies to meet both the quality and eco-friendly production [7-10], as well as, to reduce energy consumption. Plasma technology, ultrasonic, enzymatic processes and microwave energy are the new and alternative technologies used in the textile industry.

*Corresponding author e-mail: nanaelshemy@hotmail.com

DOI: 10.21608/EJCHEM.2018.5119.1453

C2017 National Information and Documentation Center (NIDOC) 
Safflower (CarthamusTinctorius L.) has been utilized traditionally for coloring fabrics, food and cosmetics in many countries. The flower petals contain two pigment dyeings: a) red (Carthamine), b) yellow (safflower yellow A\&B). The researchers discovered that the structure of safflower red, as well as, yellow pigment have unique structures of C-glycosyl -quinochalcone moieties that exist only in CarthamusTinctorius. In order to extract the red color, the yellow dye must be extracted first. Compared with Carthamine (red), large quantities of yellow pigments are present in safflower. Furthermore, safflower yellow is more stable than Carthamine under ultraviolet (UV) light [9]. There are many studies to investigate possibility to use yellow extracted pigments as a natural dyefor textiles $[7,8,10]$.
Current work addressed the extraction of yellow dye through innovative extraction from safflower petals and investigates the dyeing properties of extracted safflowers yellow coloring on wool, silk and wool/polyester blend fabric for the standardization of coloring process, as well as, color reproducibility. The innovation is based on the extraction under the influence of heat induced by microwave irradiation (MW) and compared with the nontraditional technique (WB). The extraction was conducted under different conditions. For best standardization and color reproducibility of the coloring process, dyeing powder was prepared so it could be controlled in dyeing concentration. The prepared dyeing was characterized in terms of dyeability and color on different fabrics.

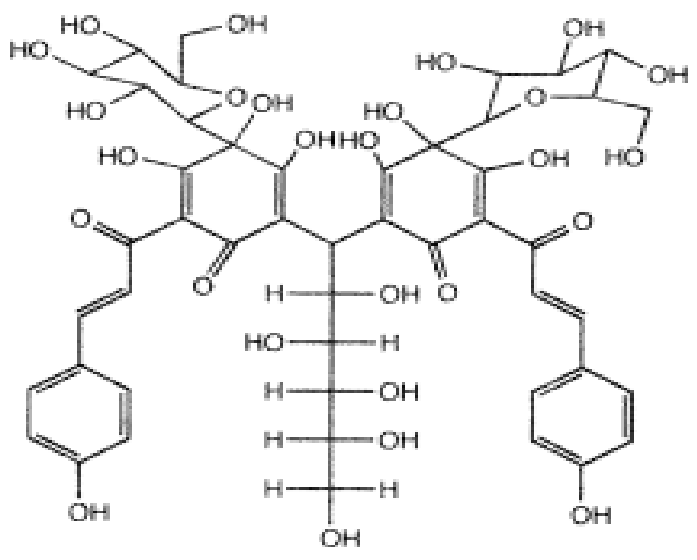

Safflor yellow B

Fig. 1. Structure of safflower yellow dye.

\section{Experimental and Methods}

Materials

Natural coloring Matter

Dry safflowers (Binomial name:

Carthamustinctorius) were purchased from an Egyptian local market. Its properties and its chemical structure are listed in Table 1.

Fabrics

- Wool, Silk and wool/polyester blend fabrics which found comprehensive use in daily life, were used in this study.

\section{Methods}

Extraction of natural yellow coloring matter:

The safflowers (Carthamustinctorius)petals were peeled and crushed to the powder form.
Then the coloring matter was extracted using different concentrations $(0.5-7 \mathrm{~g} / 100 \mathrm{ml}$ water $)$, different $\mathrm{pH}$ (2-11), different liquor ratio $(1: 20$, $1: 50$ and $1: 100)$ at different temperatures $40-80^{\circ} \mathrm{C}$ for interval times (5-30 min) using microwave synthesis systems. On using non-traditional heating, the extraction was carried out at (40$100^{\circ} \mathrm{C}$ ) for $(10-60 \mathrm{~min})$. In the end, the solution was filtered off and left to cool down.

\section{Optimization of Dyeing Conditions}

Fabrics dyeing: Wool, silk and wool/polyester blend fabrics samples were dyed (simultaneously and pre-extraction dye solution) with the natural coloring matter extracted from safflowers (Carthamustinctorius) simultaneously with liquor ratio 1:100. Dyeing was carried out simultaneously 
TABLE 1. Scientific classification of safflowers:

\begin{tabular}{cc}
\hline Kingdom & Plantae \\
\hline Clade & Angiosperms \\
Clade & Eudicots \\
Clade & Asterids \\
Order & Asterales \\
Family & Asteraceae \\
Genus & Caethamus \\
Species & C.Tinctorius \\
\hline
\end{tabular}

at $\mathrm{pH} 4$ for 10 minutes for wool, $15 \mathrm{~min}$ for wool/ polyester blend fabrics at $80^{\circ} \mathrm{C}$ and $15 \mathrm{~min}$ for silk at $40 \mathrm{oC}$ when using MW irradiation. While when using WB heating, the fabric samples were immersed in the dyeing solution in a water bath at $70^{\circ} \mathrm{C}$ then raised to $100 \mathrm{oC}$ for $60 \mathrm{~min}$. for all fabrics at $\mathrm{pH}$ 4. At the end of dyeing the dyed samples were rinsed with cold water and washed for 15 minutes in a bath containing $(3 \mathrm{~g} / \mathrm{L})$ of non-ionic detergent (Hostapal, Clariant, Swiss) at $30^{\circ} \mathrm{C}$. Finally, the fabrics were rinsed and air dried.

\section{Apparatuses}

Microwave Heating System

Extractions were carried out using microwave systems: Lab station, which is equipped with a magnetic stirrer, and a non-contact infrared continuous feedback temperature system, MILSTON, USA.

\section{Evaluation of Color Characteristics and Dye Uptake.}

Evaluation of colorimetric properties

The color strength $(K / S)$ : The color strength $(\mathrm{K} / \mathrm{S})$ invisible region of the spectrum (400-700 $\mathrm{nm}$ ) was calculated based on Kubelkae- Munk equation:

$$
\frac{K}{S}=\frac{(1-R)^{2}}{2 R} \ldots \ldots \ldots \ldots \ldots \ldots(1)
$$

Where, $(\mathrm{K})$ is adsorption coefficient, $(\mathrm{R})$ is reflectance of dyed sample and (S) is scattering coefficient [11].

The colorimetric properties of dyed fabrics were obtained with Hunter Lab DP-9000 ColorSpectrophotometer.

Color data CIELAB space: The total difference CIE (L*, a* $\mathrm{b}^{*}$ ) was measured using the HunterLab spectrophotometer (model: Hunter Lab DP9000).CIE (L*, a* $\mathrm{b}^{*}$ ) between two colors each given in terms of $\mathrm{L}^{*}, \mathrm{a}^{*}, \mathrm{~b}^{*}$ is calculated from:

- $\quad\left(\mathrm{L}^{*}\right)$ value: indicates lightness, $(+)$ if sample is lighter than standard, (-) if darker.

- $\left(a^{*} \& b^{*}\right)$ values: indicate the relative positions in CIE Lab space of the sample and the standard, from which some indication of the nature of the difference can be seen.

\section{Fastness properties}

Fastness properties to washing, rubbing (dry \&wet), perspiration, as well as, light fastness were measured according to a standard method [12].

\section{Characterization and measurements}

Calculation of Absorption Kinetics: A study of the kinetics for the adsorption process has been made to clarify the mechanism behind the process and the potential rate controlling steps such as chemical reaction, dye diffusion control, etc. [13]. The two kinetic models, namely (pseudo-first and pseudo-second orders) have been investigated in the context of these experimental results.

Pseudo First order kinetics: The pseudo-first order kinetic equation is expressed as [Y.S. Ho, and G. McKay (1999)]:

$$
\operatorname{Ln}\left(q_{e}-q_{t}\right)=\operatorname{Ln}\left(q_{e}\right)-k_{1} t
$$

Where $k_{1}$ is the Laguerre rate constant of absorption $\left(\mathrm{min}^{-1}\right), q_{e}$, and $q_{t}$ are the equilibrium absorption capacity and the absorption at time $t$ respectively, measured in units are $\mathrm{mg} / \mathrm{g}$. For the absorption process following this kinetic equation, a linear fit of $\operatorname{Ln}\left(q_{e}-q_{t}\right)$ against is plotted. The values of $k_{1}$ and $q_{e}$ have been deduced from the slope and intercept of the fitted straight line. For determining the parameters, we have fitted the mean experimental values to the theoretical equation and only these values have been plotted. 
Pseudo Second order kinetics: The time dependence of the absorption capacity according to thepseudo-second order model is expressed as follows [14]

$$
t / q_{t}=1 / K_{2} q_{e}^{2}+t / q_{e}
$$

Where $k_{2}$ is the pseudo-second order rate constant from absorption(g/mg.min), $q_{e}$ and $k_{2}$ are again deduced from the slope and intercept of the plot of ${ }^{t} / q_{t}$ against $t$. Similar to the first order case, a plot of $t / q_{t}$ against $t$ should produce astraight line. This plot using the mean values of $q_{t}$.

\section{Adsorption isotherm studies}

Langmuir isotherm: The Langmuir model assumes that absorption occurs on a homogeneous surface and there are no interactions between the adsorbate molecule in the plane of the surface and they form a monolayer. The equation for the Langmuir isotherm [14] is given as:

$$
C_{e} / q_{e}=C_{e} / q_{\text {mqx }}+1 / q_{\max } K L
$$

Where $C_{e}$ is the dye solution concentration at equilibrium of the $(\mathrm{mg} / \mathrm{L}), \quad q_{\max }$ is the maximum desorption capacity $(\mathrm{mg} / \mathrm{g}), q_{e}$ is the equilibrium adsorption capacity $(\mathrm{mg} / \mathrm{g})$ and $k L$ is a Langmuir constant $(\mathrm{L} / \mathrm{g})$ related to the dye affinity towards the binding sites and energy of adsorption

Freundlich isotherm: The Freundlich equation is based on the adsorption of a heterogeneous surface. The equation for Freundlich isotherm [15] is given as:

$$
L n q_{e}=L n K_{f}+1 / n\left(L n C_{e}\right)
$$

Where $k_{f}$ is a Freundlich constant related to the adsorption capacity $(\mathrm{L} / \mathrm{g}), 1 / n$ is an empirical parameter related to adsorption intensity. The Freundlich Isothermcurve has suggested a relationship between $C_{e}$ and $q_{e}$ is followed by experimental mean values.

\section{Calculation of Adsorption kinetics:}

The absorption kinetics of Safflower petals natural dye $(2 \%$ O.W.F.) onto wool, silk, wool/ polyester blend fabric was performed at $\mathrm{pH}$ 4, with L:R 1:100, at $80^{\circ} \mathrm{C}$ for wool and wool/ polyester and at $40{ }^{\circ} \mathrm{C}$ for silk fabric for $10,15,20$ min respectively. The dye concentration $\mathrm{qt}(\mathrm{mg} / \mathrm{g}$ fabric) at time min was calculated using massbalance relationship (Eq1.).

$$
q_{t}=\left(C_{0}-C_{t}\right) \times V / W \cdots \cdots
$$

where, $C o$ and $C t$ are the initial dye concentration $(\mathrm{mg} / \mathrm{L})$ and the dye concentration $(\mathrm{mg} / \mathrm{L})$ at dyeing time $t$ respectively, $V$ is the volume of dye solution (L), and $W$ is the fabric weight $(\mathrm{g})$.

\section{Calculation of Adsorption Isotherms}

The adsorption isotherms of safflower yellow dyeing dye on wool, silk, and wool/polyester blend fabric were investigated in series of dye concentration varying from $0.5-5 \%$ (O.W.F.) using L.R 1:50 at $80^{\circ} \mathrm{C}$ for wool and blend fabric and at $40^{\circ} \mathrm{C}$ for silk.

The adsorption isotherms were determined until reached to the equilibrium; adsorption was reached in a min when using MW irradiation, while it reached in2-3 hrs when using WB heating. The amount of dye adsorbed per unit weight of fabric at equilibrium $q_{e}(\mathrm{mg} / \mathrm{g}$ fabric) was calculated (Eq. 2) as follows:

$$
q_{e}=\left(C_{0}-C_{e}\right) \times V / W
$$

Where, $C_{o}$ is the initial dye concentration $(\mathrm{mg} / \mathrm{L}), C_{e}$ is the equilibrium dye concentration $(\mathrm{mg} / \mathrm{L}), V$ is the volume of dye solution $(\mathrm{L})$, and $W$ is the weight of fabric (g).

\section{Calculation of KineticsAbsorptionIsotherm \\ Half dyeing time $t_{1 / 2}$ ( $\left.\mathrm{min}\right)$}

After equilibrium, every dyed sample was removed and remaining extracted dye solution was kept to measurement the dye concentration in the dye solution by employing a Shimadzu spectrophotometer [16]. The half dyeing period ( $t_{1 / 2} \mathrm{~min}$ ), that is the period needed for the fabric to take up half of the amount of dye at equilibrium, is approximated by plotting the dye uptake (the dye concentration in the fiber $\mathrm{mg} / \mathrm{g}$ ) versus dyeing period, and $\left(t_{1 / 2} \mathrm{~min}\right)$ is recognized from the corresponding curves.

\section{Specific dye rate constant $(K)$}

The specific dyeing rate constant $(\mathrm{K})$ can be further estimated by using equation (8) [17]:

$$
K=0.5 C_{\infty}\left(d / t_{1 / 2}\right)^{1 / 2} \ldots \ldots \ldots \ldots \text { (8) }
$$

Where: $\mathrm{C} \infty$ is the percentage of the dye absorbed onto the sample at equilibrium condition, $\mathrm{d}$ is the fiber diameter in $\mathrm{cm}$. 
Dye Affinity $\left(-\Delta \mu^{\circ}\right)$

A $3 \%$ of weighted fabrics (O.W.F) were as performed on untreated and treated polyester fabric, at $\mathrm{pH} 4$ for $30 \mathrm{~min}$ and $60 \mathrm{~min}$. The dyed examples were treated with $80 \mathrm{ml}$ of distilled water in a stoppered flask at $80^{\circ} \mathrm{C}$ for $2 \mathrm{hr}$. The supplementary samples were comparably treated at $60^{\circ} \mathrm{C}$ for $4 \mathrm{hr}$. At the end of the prescribed time, the samples were instantly removed and rinsed countless periods alongside chilly distilled water $[18,19]$. The amount of the dye in the adsorption and rinsing solution were determined spectrophotometrically. The partition coefficient $(\mathrm{k})$ of the dye is determined from equation (9):

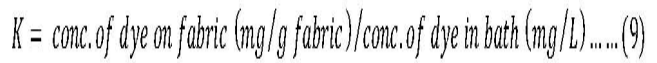

The dye affinity $\left(-\Delta \mu^{\circ}\right)$ is determined according to equation (10):

$$
-\Delta \mu=2.3 R T \log K\left(J \cdot \mathrm{mol}^{-1}\right) \ldots \ldots \ldots(10)
$$

Where $\mathrm{R}$ is the gas constant and $\mathrm{T}$ is the absolute temperature.

\section{Results and Discussion}

Optimum Conditions for the extracted safflower yellow dyeing material:

The effects of extracted dyeing parameters, such as dye amount, $\mathrm{pH}$, temperature, liquor ratio, and extracted dyeing time were investigated to obtain the optimum conditions for adsorption of safflower yellow dyes onto fabrics under study.
Effect of initial extracted dye amount on dye absorption onto different fabrics

This step was carried out by using two techniques to extract the yellow dyeing material from safflower petals (pre(extraction then dye fabric in another bath) and simultaneous (extraction and dye in one bath) at pH 4, L.R 1:100, at different dye amounts and temperature for $30 \mathrm{~min}$ in $\mathrm{MW}$ and $120 \mathrm{~min}$ in WB. Tables $2 \& 3$ show the effect of dye amount on the ability of dye adsorbing in terms of $\mathrm{K} / \mathrm{S}$ values. The force responsible for dye removal from dye bath to different types of fabrics is concentration gradient function of dye in two phases (dye solution and fiber). The data listed in Tables $2 \& 3$ reveal a number of findings as follows: a) the simultaneously extracted method gave higher $\mathrm{K} / \mathrm{S}$ values than the pre-extraction dyed method, b) the K/S values are higher in the case of MW compared with WB technique, c) the highest $\mathrm{K} / \mathrm{s}$ values are obtained at $80^{\circ} \mathrm{C}$ in $\mathrm{MW}$ and at $100^{\circ} \mathrm{C}$ in WB) the extent of dye transfer from dye solution onto the fabrics was enhanced with increase in dye bath amount, and thus apparent shades depth also increased, until 4g/100 ml when using MW irradiation and at $5 \mathrm{~g} / 100 \mathrm{ml}$ in case of WB technique, after that it dramatically decreased.

Since the main components of safflower yellow dyeing, has carbonyl groups $(\mathrm{C}=\mathrm{O})$ in its structure and protein fabric has $-\mathrm{NH}_{2}$ group as shown in Fig. 2, the dye molecules were negatively charged in $\mathrm{pH} 4$ dye bath. When the wool as well as silk protein with an isoelectric point of $\mathrm{pH} 4$, negative charges in the dye bath, was

TABLE 2. Effect of simultaneous extracted dye amount on color strength (K/S) of different dyeing fabrics.

\begin{tabular}{|c|c|c|c|c|c|c|c|c|c|c|c|c|}
\hline \multirow{4}{*}{$\begin{array}{c}\text { Dye } \\
\text { conc. } \\
\text { g/100 } \\
\text { ml }\end{array}$} & \multicolumn{12}{|c|}{ Color strength $(\mathrm{K} / \mathrm{S})$} \\
\hline & \multicolumn{4}{|c|}{ Wool } & \multicolumn{4}{|c|}{ Silk } & \multicolumn{4}{|c|}{ Wool/polyester } \\
\hline & \multicolumn{2}{|c|}{ MW } & \multicolumn{2}{|c|}{ WB } & \multicolumn{2}{|c|}{ MW } & \multicolumn{2}{|c|}{ WB } & \multicolumn{2}{|c|}{ MW } & \multicolumn{2}{|c|}{ WB } \\
\hline & $40^{\circ} \mathrm{C}$ & $8^{\circ} \mathrm{C}$ & $40^{\circ} \mathrm{C}$ & $100^{\circ} \mathrm{C}$ & $40^{\circ} \mathrm{C}$ & $80^{\circ} \mathrm{C}$ & $40^{\circ} \mathrm{C}$ & $100^{\circ} \mathrm{C}$ & $40^{\circ} \mathrm{C}$ & $8^{\circ} \mathrm{C}$ & $40^{\circ} \mathrm{C}$ & $100^{\circ} \mathrm{C}$ \\
\hline 0.5 & 6.68 & 15.84 & 3.83 & 12.55 & 6.41 & 4.37 & 3.15 & 2.44 & 2.71 & 2.95 & 1.08 & 1.10 \\
\hline 1.0 & 7.55 & 18.91 & 4.03 & 16.79 & 9.24 & 6.62 & 4.52 & 3.88 & 3.22 & 3.31 & 1.87 & 1.31 \\
\hline 1.5 & 8.70 & 21.72 & 4.25 & 17.70 & 11.52 & 7.76 & 5.55 & 4.39 & 3.67 & 3.69 & 1.89 & 1.46 \\
\hline 2.0 & 8.86 & 24.02 & 5.07 & 18.08 & 11.8 & 8.57 & 6.92 & 5.41 & 3.75 & 4.19 & 2.12 & 1.49 \\
\hline 2.5 & 9.49 & 25.72 & 8.36 & 21.57 & 11.52 & 9.46 & 7.72 & 6.74 & 3.85 & 4.38 & 2.10 & 1.92 \\
\hline 3.0 & 11.13 & 30.17 & 10.6 & 22.04 & 12.53 & 9.80 & 8.95 & 7.76 & 4.14 & 4.49 & 2.17 & 2.17 \\
\hline 4.0 & 13.33 & 36.66 & 10.79 & 24.17 & 15.93 & 12.25 & 9.22 & 7.88 & 4.54 & 4.75 & 2.25 & 2.46 \\
\hline 5.0 & 12.25 & 32.14 & 10.38 & 25.50 & 15.93 & 11.85 & 10.79 & 9.27 & 4.46 & 4.70 & 2.04 & 4.84 \\
\hline 6.0 & 12.00 & 27.63 & 10.35 & 23.14 & 14.67 & 9.11 & 8.03 & 7.16 & 4.30 & 4.58 & 2.00 & 2.20 \\
\hline 7.0 & 10.74 & 26.49 & 6.93 & 23.02 & 13.72 & 8.05 & 7.3 & 6.87 & 4.22 & 4.41 & 2.00 & 2.15 \\
\hline
\end{tabular}

L.R: 1:100, $\mathrm{pH} 4$, at different temperature for $30 \mathrm{~min}$ in $\mathrm{MW}$ and $120 \mathrm{~min}$ in WB. 
TABLE 3. Effect of pre extracted dye amount on color strength $(\mathrm{K} / \mathrm{S})$ of different dyeing fabrics

\begin{tabular}{|c|c|c|c|c|c|c|c|c|c|c|c|c|}
\hline \multirow{3}{*}{$\begin{array}{l}\text { Dye conc. } \\
\text { g/100 ml }\end{array}$} & \multicolumn{12}{|c|}{ Color strength (K/S) } \\
\hline & \multicolumn{4}{|c|}{ Wool } & \multicolumn{4}{|c|}{ Silk } & \multicolumn{4}{|c|}{ Wool/polyester } \\
\hline & 1 & 2 & 3 & 4 & 1 & 2 & 3 & 4 & 1 & 2 & 3 & 4 \\
\hline 0.5 & 7.57 & 9.47 & 13.12 & 10.36 & 1.09 & 2.8 & 3.07 & 2.99 & 1.49 & 2.22 & 2.71 & 2.63 \\
\hline 1.0 & 13.52 & 15.19 & 18.93 & 15.70 & 2.98 & 2.41 & 4.71 & 3.06 & 1.87 & 2.86 & 3.31 & 3.17 \\
\hline 1.5 & 14.71 & 17.07 & 20.70 & 19.77 & 3.55 & 3.90 & 4.59 & 4.40 & 1.89 & 3.13 & 4.22 & 3.45 \\
\hline 2.0 & 15.14 & 17.99 & 20.77 & 19.97 & 3.95 & 4.35 & 5.19 & 4.35 & 2.12 & 3.69 & 5.45 & 4.33 \\
\hline 2.5 & 15.82 & 19.55 & 21.58 & 20.38 & 4.44 & 4.71 & 7.84 & 5.78 & 2.25 & 3.75 & 6.13 & 4.33 \\
\hline 3.0 & 16.66 & 20.01 & 23.67 & 20.69 & 4.89 & 6.18 & 8.93 & 7.66 & 2.85 & 4.10 & 6.41 & 5.29 \\
\hline 4.0 & 17.32 & 20.54 & 28.64 & 28.26 & 6.68 & 6.39 & 11.24 & 9.43 & 4.14 & 5.17 & 8.46 & 6.32 \\
\hline 5.0 & 20.89 & 25.73 & 27.90 & 26.53 & 7.95 & 8.36 & 10.58 & 8.83 & 4.53 & 5.24 & 7.09 & 6.61 \\
\hline 6.0 & 17.55 & 25.15 & 28.02 & 26.45 & 7.50 & 8.48 & 10.25 & 9.27 & 4.54 & 5.25 & 6.63 & 4.54 \\
\hline 7.0 & 20.68 & 23.45 & 27.65 & 24.26 & 7.50 & 7.92 & 9.89 & 9.26 & 4.51 & 5.25 & 6.59 & 4.56 \\
\hline
\end{tabular}

1) Extracted at $40^{\circ} \mathrm{C}$ for $120 \mathrm{~min}$ and dyed at $100^{\circ} \mathrm{C}$ for $30 \mathrm{~min}$ by using $\left.\mathrm{WB}, 2\right)$ Extracted using $\mathrm{WB}$ at $40^{\circ} \mathrm{C}$ for $120 \mathrm{~min}$ and dyed in MW for $30 \mathrm{~min}$ at $80^{\circ} \mathrm{C}, 3$ ) extracted at $40^{\circ} \mathrm{C}$ and dyed at $80^{\circ} \mathrm{C}$ in $\mathrm{MW}$ for $30 \mathrm{~min}$. for both, 4) MW extracted at $40^{\circ} \mathrm{C}$ for $30 \mathrm{~min}$ and $\mathrm{WB}$ dyed at $100^{\circ} \mathrm{C}$ for $30 \mathrm{~min}$, at $\mathrm{pH} 4$ for all.

a repulsive electrostatic force between safflower dye molecules and protein fabric molecules. With the addition of acetic acid, the repulsion can be decreased and adsorption of safflower dye on fabrics can be improved. The increasing trends were not obvious with the increase of dye amount from 4.0 to $7.0 \mathrm{~g} / \mathrm{L}$ in case of MW irradiation and from 5.0 to 7.0 in $\mathrm{WB}$ technique.

From the colorimetric parameters (CIE $\left(L^{*}, a^{*} \& b^{*}\right)$, and $\left(L^{*} \& b^{*}\right)$ (Tables $\left.4 \& 5\right)$ and visual inspection, it is evident that wool, silk and wool / polyester samples dyed with extracted safflower yellow dyeing materials showed yellowish color with high lightness $\left(L^{*}\right)$ indicating light and bright shades. From $\left(a^{*} \& b^{*}\right)$ data listed in Tables 4,5 , it can be seen that the samples dyed with extracted dye were found little shifted towards yellow co-ordinate in a red-yellow zone of CIE Lab color space. The shift towards yellow co-ordinate was higher in case of untraditional heating (MW) compared with traditional one (WB). In general, all samples dyed with lower dye amount were light, bright, and less saturated than samples dyed with higher dye amount.
Effect of $\mathrm{pH}$ on stability of safflower Liquor and colors of dyed fabrics

Generally, the $\mathrm{pH}$ of dye solution plays an important role in controlling dye absorption capacity on textile materials. In order to find optimum extracted and dyeing $\mathrm{pH}$, various dyeing experiments in the $\mathrm{pH}$ range of 2-11 were conducted. Figure 3 shows the stability of extracted dye in dye liquor after being simultaneously extracted $4 \mathrm{~g} / 100 \mathrm{ml}$ dye, L.R. 1:100 for $30 \mathrm{~min}$ at $80^{\circ} \mathrm{C}$ when using MW. While when using WB, the extraction of $5 \mathrm{~g} / 100 \mathrm{ml}$ carried out at $100^{\circ} \mathrm{C}$ for $60 \mathrm{~min}$ for all fabric.

Comparing with WB, as well as, MW dye liquor, safflower yellow dye liquor with $\mathrm{pH}$ 4 showed the highest K/S values for all dyed fabrics and after that with $\mathrm{pH} \mathrm{7,9}$ and 11showed an obvious decrease of $\mathrm{K} / \mathrm{S}$ values. The decrease of $\mathrm{K} / \mathrm{S}$ values may be caused by the precipitation or degradation of dye in an alkaline medium. In solutions with higher $\mathrm{pHs}$, more hydroxyl groups of dye could dissociate into $\mathrm{R}-\mathrm{O}^{-}$anions, resulting in higher solubility of safflower yellow dye.

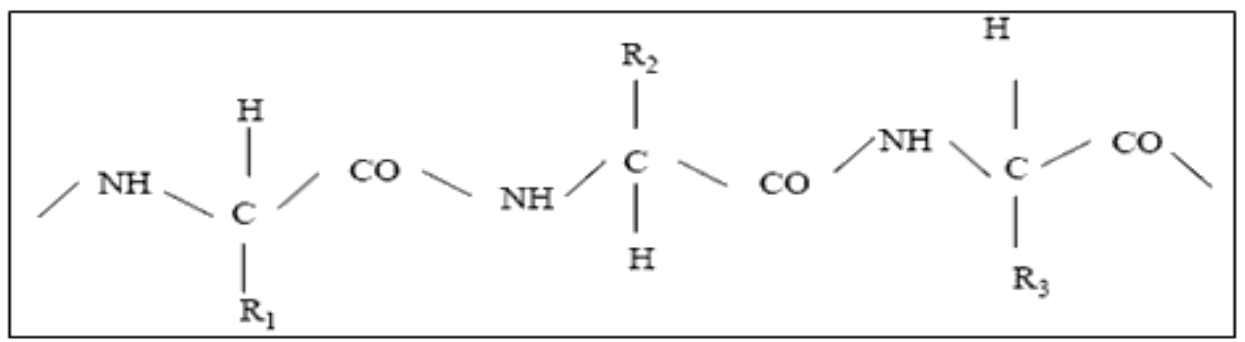

Fig. 2. Structure of protein fiber. 
TABLE 4. Lightness $\left(L^{*}\right)$, Redness-Greenness Value $\left(a^{*}\right)$, Yellowness-Blueness Value $\left(b^{*}\right)$, and $(\Delta E)$ of wool, silk, and wool/polyester blend fabrics coloured with safflower yellow dyeing simultaneously at different concentrations and different temperatures using MW irradiation.

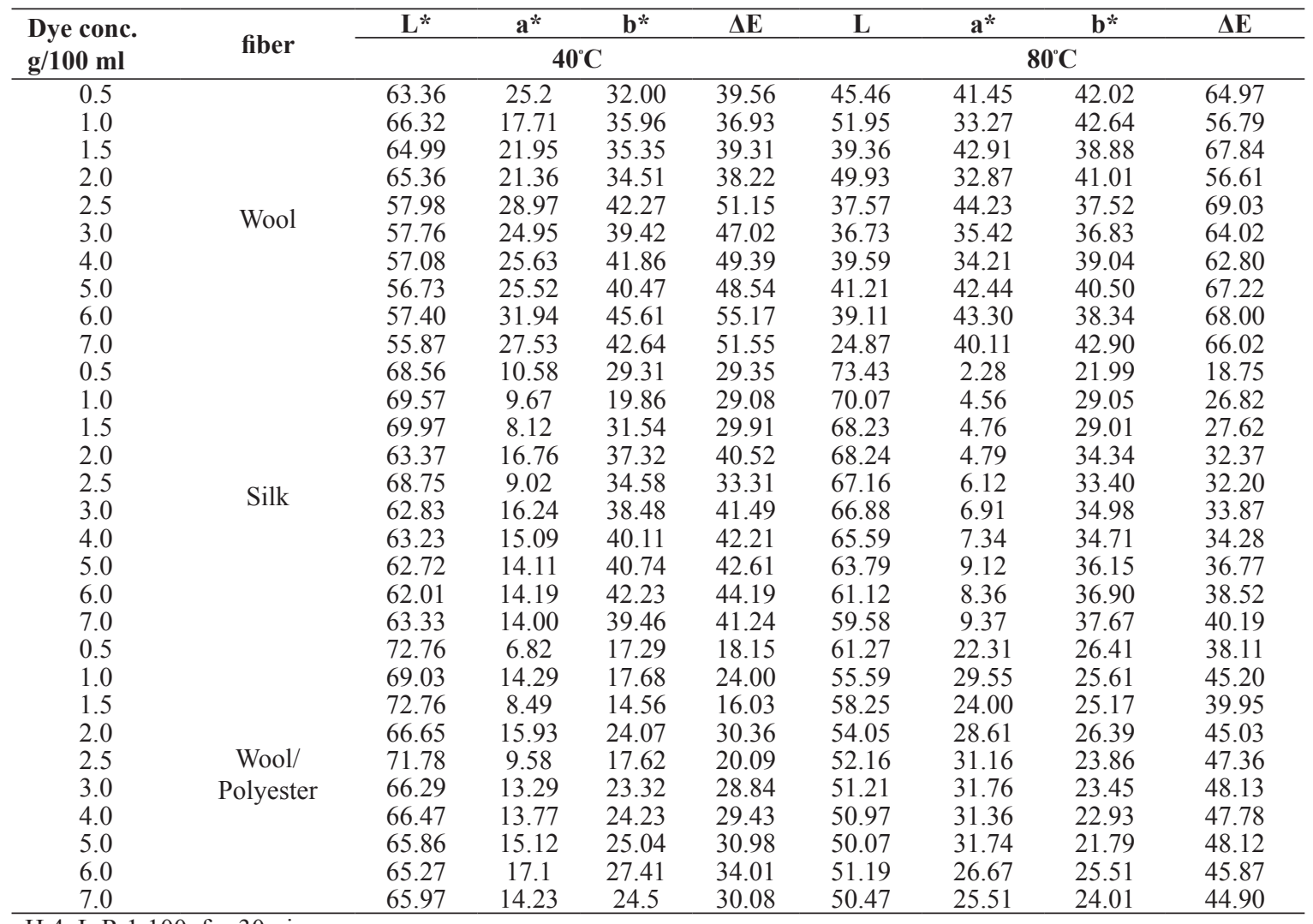

pH 4, L:R 1:100, for 30min.

dye anion combines with protein fabric. However, dye bath with $\mathrm{pH} 4$ could be selected since extracted dye has good solubility which facilitates achieving deep colour, moreover, wool, silk and wool/polyester blend fabrics may not be damaged seriously at this $\mathrm{pH}$.

Table 6 shows the colorimetric data $\left(L^{*}, a^{*}\right.$ and $b^{*}$ ) of different fabrics dyed with different simultaneous extracted dye bath $\mathrm{pH}$. From the data listed in Table 6, it can be concluded that increasing of the extracted dye path $\mathrm{pH}$, is accompanied by increasing of $L^{*}$ values and thus color of samples got lighter. By growing the dye bath $\mathrm{pH}, a^{*}$ values decrease in the positive direction while $b^{*}$ values increased in the same direction. The color of dyed simultaneous fabrics turned to more yellowish red color and became lighter with increasing the dye bath $\mathrm{pH}$ from 2-4 and thereafter the fabrics are turned to more brownish yellow color.

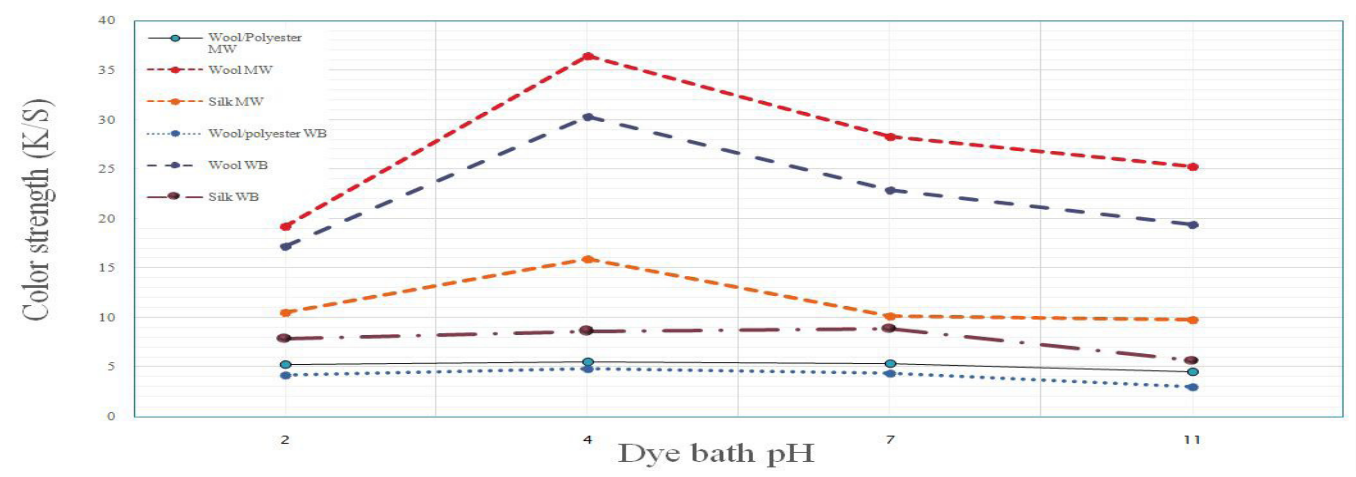

Fig. 3. Effect of dye bath pH on the stability of safflower yellow dyeing dye solution of different fibers. 
TABLE 5. Lightness $\left(L^{*}\right)$, Redness-Greenness Value ( $\left.a^{*}\right)$, Yellowness-Blueness Value $(b *)$, and $(\Delta E)$ of wool, silk, and wool/polyester blend fabrics coloured with safflower yellow dyeing simultaneously at different concentrations and different temperatures using WB technique

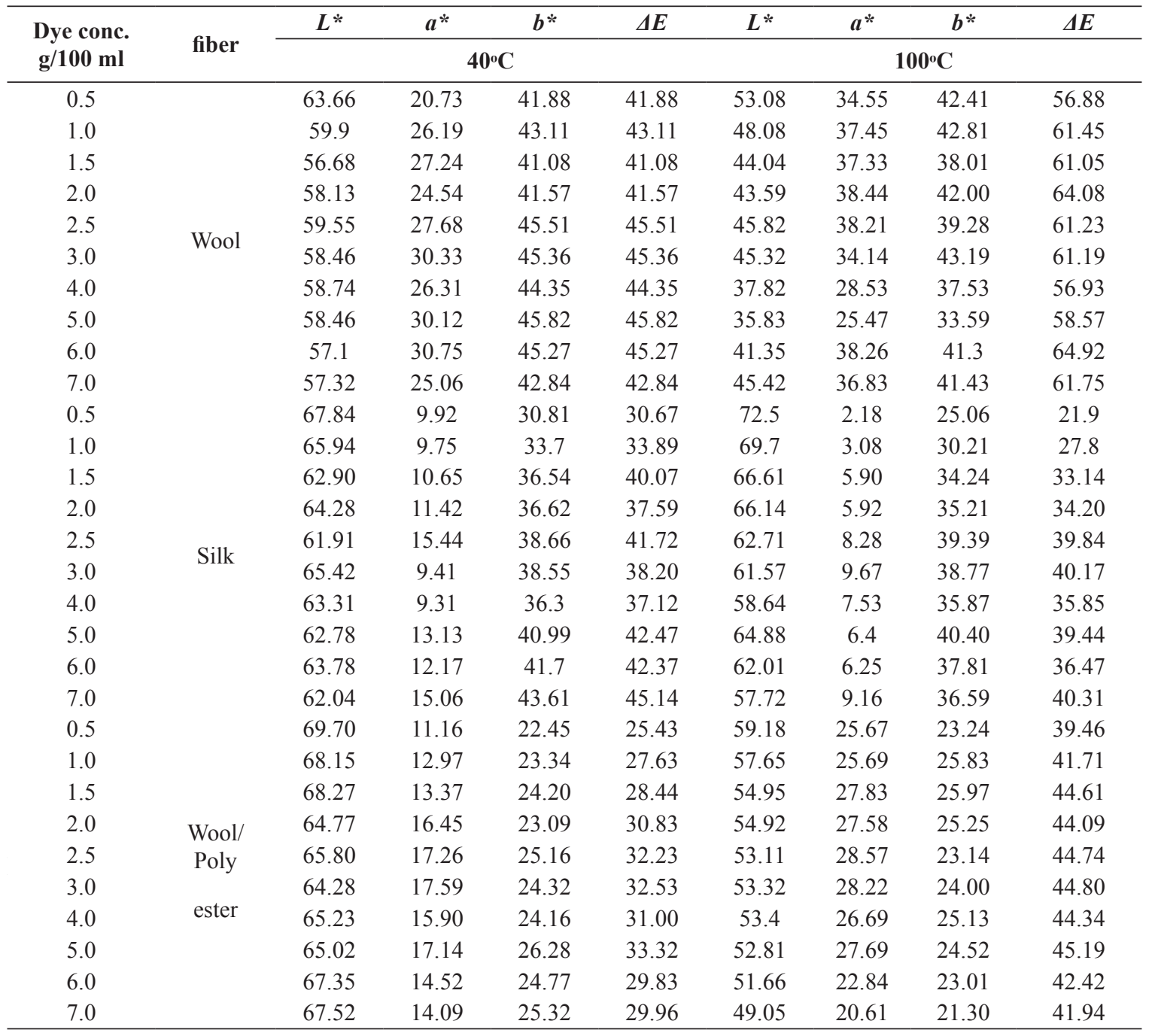

PH 4, L:R 1:100, for 120 min.

Effect of temperature on absorption of safflower yellow dye onto different fabrics

Temperature affects the mechanism of dyeing process through altering the energy of dye molecules in dye-bath which cause fabric swelling extent and makes their interaction practicable to absorption. The result of the study of the effect of temperature on the absorption of safflower yellow dyes onto the different fabric at $\mathrm{pH} 4$ with an initial dye concentration of $4 \mathrm{~g} / 100 \mathrm{ml}$ for 30 min in MW is illustrated by Fig. $4 \mathrm{~b}$ and $5 \mathrm{~g} / 100 \mathrm{ml}$ for $60 \mathrm{~min}$ in WB (Fig. 4a). It can be clearly concluded that with an increase in temperature, dye absorption increases first due to the more swelling extent of fabric at high temperatures. Dye exhaustion was observed highest at $40^{\circ} \mathrm{C}$ for silk and wool fabrics and at $60^{\circ} \mathrm{C}$ for wool/ polyester fabric on using MW irradiation while using $\mathrm{WB}$, it occurred at $100^{\circ} \mathrm{C}$ for all fabrics and after that with an increase in temperature dye absorption was decreased owing to the shift of adsorption-desorption equilibrium towards right. This indicates that absorption of safflower yellow dye onto the fabrics is controlled by an exothermic process. This may be elucidated by the flagging of hydrogen bonds, as well as, Vander Waals forces of attractions between absorbed dye and fabrics at higher temperatures [20].

Effect of dyeing time on dye absorption onto different fabrics

The saturated absorption time is fundamental in describing the adsorbate-absorbent interactions. Simultaneous safflower dye extraction by using WB and MW were carried out for different times 
TABLE 6. CIE Lab coordinates at different extracted dye bath $\mathrm{pH}$.

\begin{tabular}{|c|c|c|c|c|c|c|c|c|}
\hline \multirow{2}{*}{ pH } & $L$ & $a^{*}$ & $b^{*}$ & $\Delta E$ & $L$ & $a^{*}$ & $b^{*}$ & $\Delta E$ \\
\hline & \multicolumn{4}{|c|}{ MW irradiation } & \multicolumn{4}{|c|}{ WB heating } \\
\hline \multicolumn{9}{|c|}{ Wool } \\
\hline 2 & 35.69 & 30.36 & 35.86 & 62.25 & 41.59 & 26.58 & 39.58 & 62.48 \\
\hline 4 & 39.05 & 24.68 & 36.25 & 64.8 & 45.29 & 30.99 & 42.00 & 59.23 \\
\hline 7 & 44.02 & 36.06 & 45.7 & 49.88 & 45.32 & 30.75 & 47.60 & 57.55 \\
\hline 11 & 57.13 & 10.76 & 43.66 & 44.83 & 62.79 & 15.92 & 47.37 & 46.85 \\
\hline \multicolumn{9}{|c|}{ Silk } \\
\hline 2 & 58.39 & 23.09 & 44.92 & 49.36 & 59.78 & 23.23 & 32 & 47.57 \\
\hline 4 & 61.39 & 19.69 & 44.72 & 48.16 & 63.03 & 18.81 & 41.17 & 46.14 \\
\hline 7 & 65.31 & 18.31 & 42.84 & 44.97 & 63.72 & 18.66 & 42.58 & 44.36 \\
\hline 11 & 66.39 & 14.28 & 32.66 & 35.95 & 66.29 & 16.82 & 43.53 & 35.73 \\
\hline \multicolumn{9}{|c|}{ Wool / polyester } \\
\hline 2 & 49.94 & 23.59 & 23.09 & 42.81 & 52.18 & 24.97 & 25.92 & 45.63 \\
\hline 4 & 54.33 & 22.67 & 24.05 & 39.35 & 54.74 & 26.52 & 26.55 & 44.35 \\
\hline 7 & 55.23 & 19.31 & 27.34 & 40.01 & 54.99 & 27.88 & 28.63 & 42.02 \\
\hline 11 & 65.24 & 8.00 & 30.51 & 32.07 & 67.64 & 10.21 & 30.96 & 32.16 \\
\hline
\end{tabular}

$4 \mathrm{~g} / 100 \mathrm{ml}$ for $30 \mathrm{~min}$ in $\mathrm{MW}$ and $5 \mathrm{~g} / 100 \mathrm{ml}$ for $60 \mathrm{~min}$ in WB, L:R 1:100
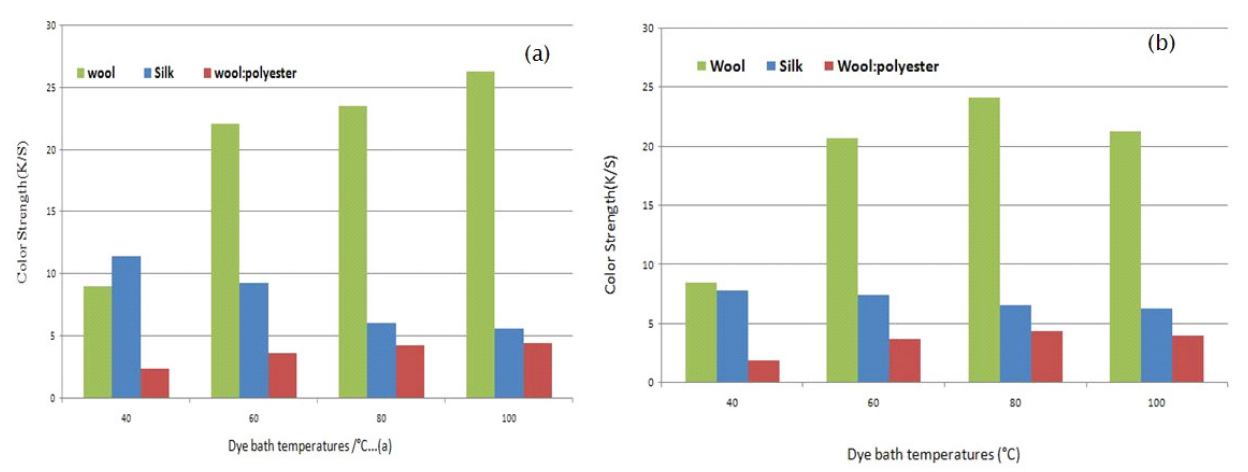

Fig. 4. Effect of temperature on absorption of safflower yellow dye onto different fabrics: (a) WB, (b) MW.

(5-30 $\mathrm{min})$ and (20-60 $\mathrm{min})$ when using WB. Figure 5 reveals the effect of extracted time on dye uptake of different fabrics by using WB (Fig.5 (a)) as well as MW (Fig.5 (b)) irradiation. The figures demonstrate that the dye uptake by MW irradiation is higher than WB revealing maximum dye extraction after 20,10 and 15 min for silk; wool, and wool/polyester blend fabric respectively, while the maximum dye extraction reached after 60 min for all fabrics when using WB heating. It is worthy to notice that the prolonged extraction time by using MW irradiation lead to dye degradation as revealed by decreasing K/S for dyed fabrics. The chromaticity values are shown in Tables 6 , 7, were comparable for all dyed fabrics. The value of $L$ which represents the yellowish red effect for dyed fabric was significantly higher at MW compared to those at other WB value. This indicates that the dyed yarn using MW was yellowish red whereas the rest of other dyed fabrics were more towards yellowish brown.

Effect of dye liquor ratio on dye absorption onto different fabrics

Liquor ratio is an important factor in textile coloration especially when natural dyes are utilized. Table 7 illustrates the effect of liquor ratio on dye absorption onto different fabrics.

From all the above data we can conclude that, an initial dye concentration of $4 \mathrm{~g} / 100 \mathrm{ml}$ in MW and $5 \mathrm{~g} / 100 \mathrm{ml}$ for $\mathrm{WB}$ technique, temperature $40^{\circ} \mathrm{C}$ for silk fabric and at $80^{\circ} \mathrm{C}$ for wool and wool/ polyester blend fabrics on using $\mathrm{MW}$ irradiation and at $100^{\circ} \mathrm{C}$ when using WB technique. At 

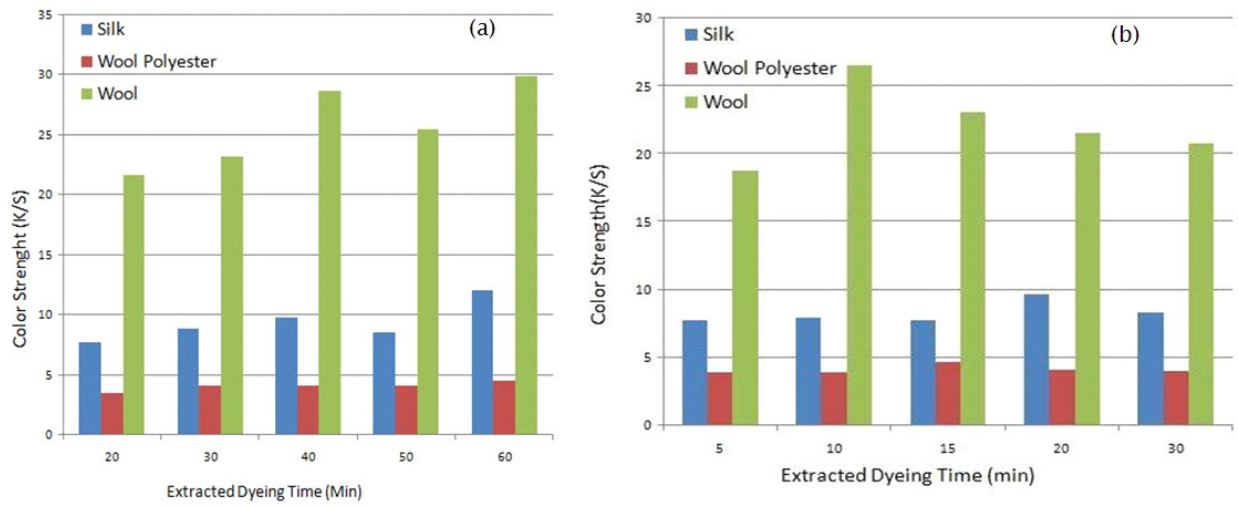

Fig. 5. Effect of extracted dyeing time on absorption of safflower yellow dye onto different fabrics: (a) WB, (b) MW.

TABLE 7. CIE Lab coordinates and (K/S) at different extracted dye path liquor ratio.

\begin{tabular}{|c|c|c|c|c|c|c|c|c|c|c|}
\hline \multirow{2}{*}{$\begin{array}{c}\text { Extracted } \\
\text { dye bath } \\
\text { LR }\end{array}$} & $\mathbf{K} / \mathbf{S}$ & $\mathbf{L}$ & $a^{*}$ & $b^{*}$ & $\Delta \mathbf{E}$ & $\mathbf{K} / \mathbf{S}$ & $\mathbf{L}$ & $a^{*}$ & $\mathbf{b}^{*}$ & $\Delta \mathbf{E}$ \\
\hline & \multicolumn{5}{|c|}{ MW irradiation } & \multicolumn{5}{|c|}{ WB heating } \\
\hline \multicolumn{11}{|c|}{ Wool } \\
\hline $1: 20$ & 25.72 & 50.79 & 30.97 & 49.82 & 60.29 & 15.74 & 46.42 & 29.28 & 44.39 & 58.23 \\
\hline $1: 50$ & 40.10 & 43.79 & 38.10 & 45.39 & 65.21 & 18.46 & 40.01 & 35.67 & 40.68 & 63.49 \\
\hline $1: 100$ & 39.91 & 46.28 & 40.09 & 48.65 & 67.00 & 25.53 & 39.39 & 38.49 & 42.49 & 66.46 \\
\hline \multicolumn{11}{|c|}{ Silk } \\
\hline $1: 20$ & 27.13 & 66.95 & 15.51 & 40.84 & 41.66 & 5.98 & 66.16 & 13.88 & 43.20 & 42.38 \\
\hline $1: 50$ & 30.21 & 66.91 & 17.49 & 44.05 & 44.87 & 7.48 & 66.53 & 16.61 & 43.28 & 44.07 \\
\hline $1: 100$ & 30.04 & 65.71 & 18.29 & 42.17 & 43.91 & 10.88 & 68.58 & 16.54 & 43.15 & 43.82 \\
\hline \multicolumn{11}{|c|}{ Wool / polyester } \\
\hline $1: 20$ & 4.44 & 55.74 & 24.26 & 31.51 & 45.02 & 4.56 & 54.47 & 20.82 & 30.84 & 43.50 \\
\hline $1: 50$ & 5.03 & 54.74 & 27.86 & 29.11 & 46.20 & 4.38 & 49.07 & 26.73 & 23.35 & 45.99 \\
\hline $1: 100$ & 4.86 & 51.47 & 29.5 & 26.9 & 47.88 & 5.21 & 47.16 & 29.35 & 21.69 & 48.17 \\
\hline
\end{tabular}

MW: $4 \mathrm{~g} / 100 \mathrm{ml}, \mathrm{pH} 4,40^{\circ} \mathrm{C}$ for silk and for $80^{\circ} \mathrm{C}$ for wool and wool/polyester for 10.20 and 15 min respectively. WB: $4 \mathrm{~g} / 100 \mathrm{ml}, \mathrm{pH} 4$, at $100^{\circ} \mathrm{C}$ for $60 \mathrm{~min}$ for all fabrics.

$\mathrm{pH}=4$ for 10,20 and $15 \mathrm{~min}$ to wool, silk and wool/polyester blend fabric in MW respectively, while for $60 \mathrm{~min}$ in WB and L.R. 1:100 used as optimized condition for determining absorption characteristics of safflower yellow natural dye.

\section{Kinetic study}

The reaction rate of any process can be defined as the change in one of the starting materials which takes place in any process or any product that obtained per unit time. When applying this definition to the dyeing process, it can be considered as the change in the dye-uptake per unit time.

Egypt. J. Chem. 62, No. 2 (2019)
Time/dye-uptake isotherms of wool, silk and wool/polyester blend fabrics microwave, as well as, traditionally dyed with safflower petals are shown in Fig. 6 (a, d). From the figures, we can observe that the dye absorption values of MW dyed fabrics are generally higher if compared with those dyed by WB technique. Note that the dyeing isotherms behaviour in this figure indicate that the isotherms of both methods started to be differentiated from each other to show higher dyeuptake for safflower dye under MW irradiation in comparison with WB heating. However, the dyeing technique is a solid/liquid phase which occurred by the transfer of dye molecule (liquid phase) to the surface of the fibre (solid phase) 
and then the dye diffusion takes place inside the fibres. Accordingly, the influence of microwave irradiation on the dyeing rate would become clear in the diffusion process which revealed higher dye-uptake in short time for MW dyed samples in comparison with WB dyed ones. This enhancement effect of MW irradiation may be due to its dielectric super heating mechanism. The increase in the kinetics of reaction by two orders of magnitude initial heating and generation of localized heat at reaction sites, thereby increasing the rate of dye absorption. As the exposure to MW irradiation increases, the absorption rate of dye ions was accelerated with remarkable enhancement of dye uptake.

The intensity of the ion-dipole resonance band at $455 \mathrm{~nm}$ was used to evaluate the concentration of safflower dye solution, quantitatively. The amount of dyestuff adsorbed on per gram of fabrics $(q t)(\mathrm{mg}$ g-1) at any time $(t)(\mathrm{min})$ was calculated by a mass-balance relationship (equation 11):

$$
q_{t}=\left(C_{0}-C_{t)} \times V\right) / W
$$

Where $C 0\left(\mathrm{mg} \mathrm{L}^{-1}\right)$ is the initial dye concentration, $C t\left(\mathrm{mg} \mathrm{L}^{-1}\right)$ is the dye concentration after any time $t$ (min). $W$ (mg) is the weight of the fibre sample and $V(\mathrm{~L})$ is the volume of the dye solution. The amount of dyestuff adsorbed on fibres at equilibrium () was calculated by use equation 12 ,

$$
q_{e}=\left(C_{0}-C_{e} \times V\right) / W
$$

Where $C e$ is the concentrations of the dye solution at equilibrium $\left(\mathrm{mg} \mathrm{L}^{-1}\right)$. The values of $q_{e}$ as a function of time for the dyeing of wool, silk, and wool/polyester fabric with safflower are plotted in Fig. 6 a and d. The adsorption amount of dye on fabrics increased with prolonged dyeing time

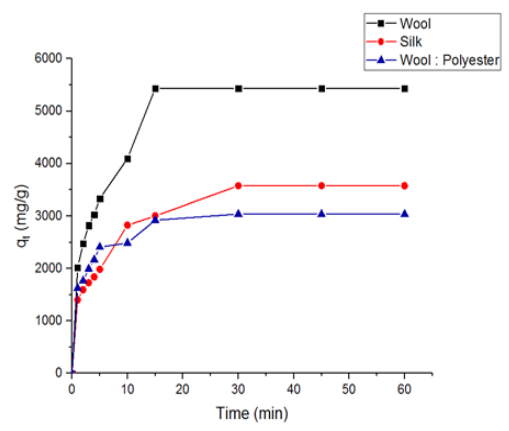

(a)

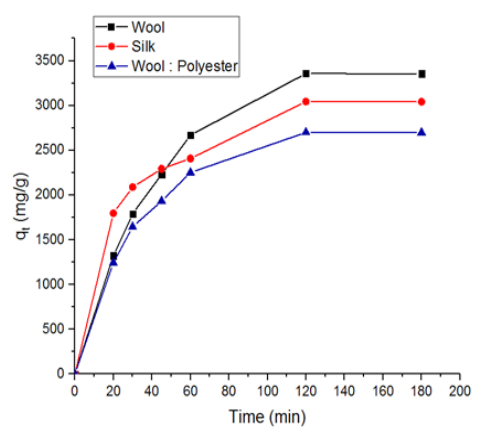

(d)

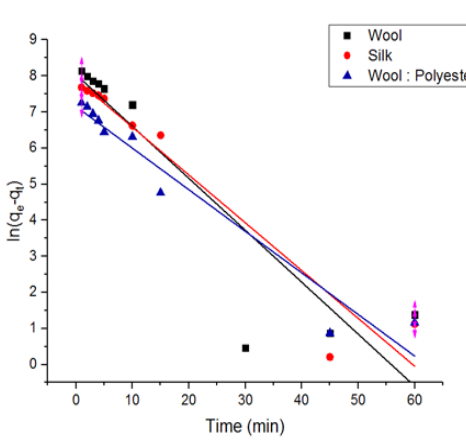

(b)

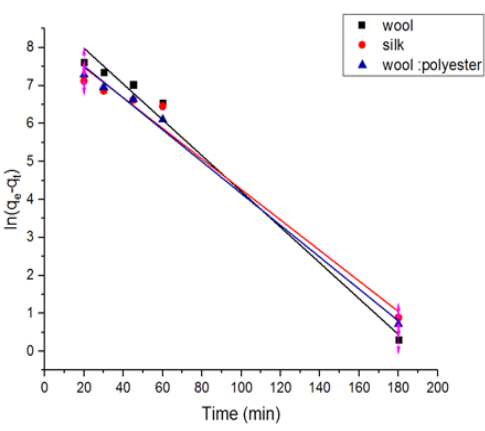

(e)

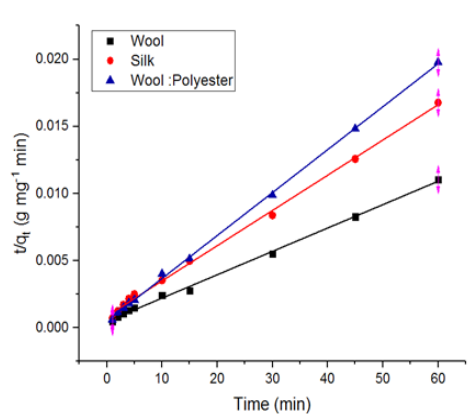

(c)

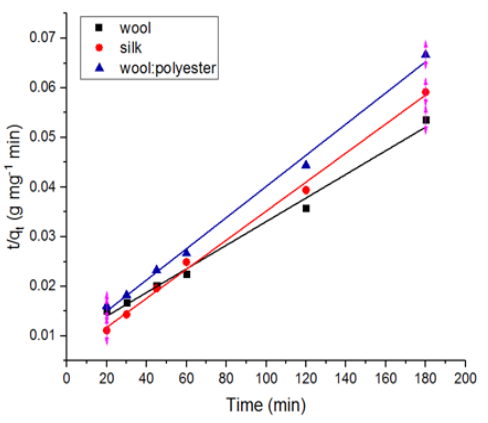

(f)

Fig. 6. Relative plots of the kinetic process for the dyeing of wool, silk, and wool/polyester with safflower dye: (a, d) $q_{t}$ vs time, (b, e) $\ln \left(q_{e}-q_{t}\right)$ vs. time and (c, f) $t / q_{t}$ vs. time dyed with MW irradiation and WB heating respectively. 


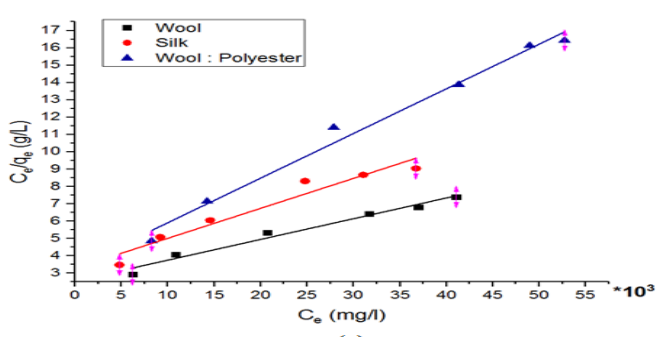

(a)

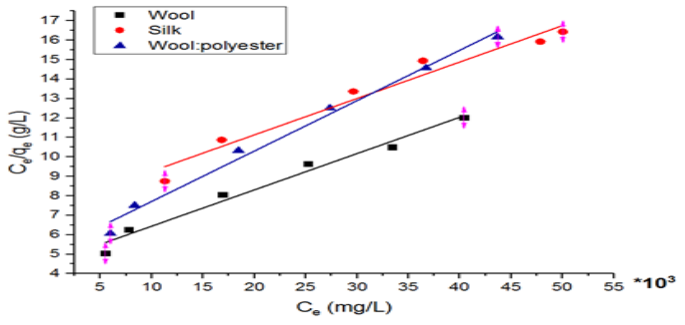

(c)
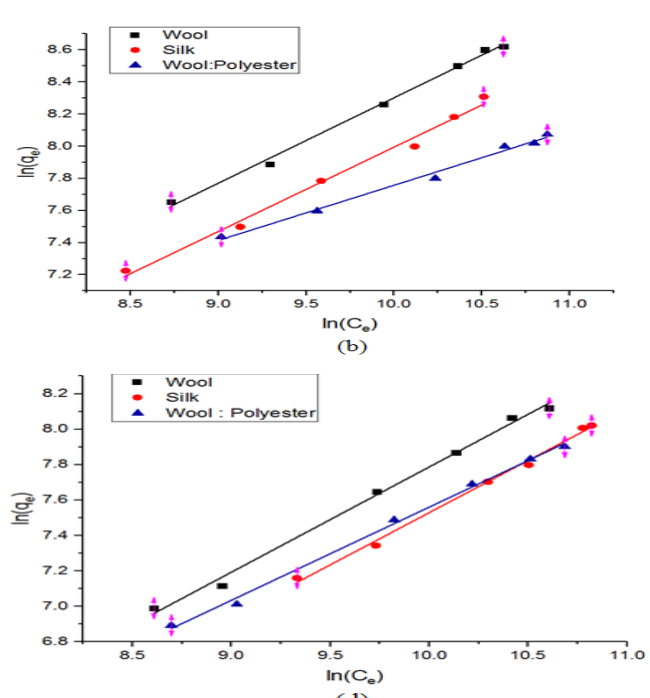

(d)

Fig. 7. Isotherm curves: (a ,c) Langmuir; and (b, d) Freundlich. For the dyeing of wool, silk, and wool/polyester with safflower dye by using MW irradiation and WB heating respectively.

and reached a plateau after a certain time. At the beginning of the dyeing process, the dye amount absorbed on the fabrics was larger than that at the end of the dyeing process. However, the final adsorption amounts of safflower dyeing materials on fabrics $(q e)$ were constant as nearly all samples and were combined with fabrics at different times.

\section{Pseudo-first and Second-order model:}

Visions into adsorption path of dyes including dye transfer, dispersal control and chemical interaction occurring between dye molecules and functional group that present in the fabrics under study are vital to investigate the dyeing mechanism. In this investigation, pseudo-firstorder, as well as, pseudo-second-order kinetic models were utilized to analyze the empirical data. The linear regression correlation coefficient (R) values were utilized to fruition the validity of the selected model. The pseudo-first-order model is considered as a simple kinetic of adsorption analysis, equation 6 can describe the kinetics of the adsorption processes [21,22].

$$
d q_{t} / d t=K_{1}\left(q_{e}-q_{t}\right) \ldots .
$$

Where: $k 1$ is the rate constant for the pseudofirst-order adsorption $\left(\mathrm{min}^{-1}\right)$, and $q_{e}$ and $q_{t}$ are the amounts of dye adsorbed on the fibres ( $\mathrm{mg}$ g-1) at equilibrium and time $t$, respectively.

Addition by applying the initial concentration $(q t=0)$ at $(t=0)$ and $\left(q=q_{t}\right)$ at $(t=t)$ we can obtain the following equation

$$
\operatorname{Ln}\left(q_{e}-q_{t}\right)=\operatorname{Ln} q_{e}-K_{1} t \ldots . .
$$

Figures 6 (b\&e) showed the plots of $\ln \left(q_{e}-q_{t}\right)$ vs. time, corresponding to the simultaneous dyeing of wool, silk, and wool polyester fabrics with safflower dyes. The experiment was performed at the optimum $\mathrm{pH} 4$ and temperature $80^{\circ} \mathrm{C}$ for wool and blend and at $40^{\circ} \mathrm{C}$ for silk while at $100^{\circ} \mathrm{C}$ when using WB for wool and blend and at $40^{\circ} \mathrm{C}$ for silk. The experimental values of $\operatorname{lin}\left(q_{e}-q_{t}\right)$ shows a reasonably good fit to the linear form. The equilibrium adsorption capacity) $\left(q_{e}^{e x p}\right)$ as well as $\left(q_{e}^{\text {theo }}\right)$ obtained in a straightforward way from the experiment and experiment were found depending on the fabric type and heating technique. The value of can be redefined by using the linear fit of the plot. The correlation coefficient $\left(r^{2}\right)$ indicates that the first order kinetics for this system is more or less suitable.

Similar to the first order case, a plot of ${ }^{t} / q_{t}$ against should produce a straight line (Fig. 6. c, f). This plot using the mean values of $q_{t}$ has been shown in Fig. 6. As we can see from the figure, the fit is practically perfect with the correlation coefficient $\left(r^{2}\right)$ value turning out to be 0.99 . The value of $q_{e}$ obtained from the linear fit, $q_{e}^{\text {the }}$ turns out to be very close to the experimental value. These facts authoritatively prove that a second order equation is much more appropriate than a first order one for dye fabric by safflower yellow dyeing. This is a consequence of the fact 
TABLE 8. The values of the constants obtained for pseudo $1^{\text {st }}$ and $2^{\text {nd }}$ order.

\begin{tabular}{|c|c|c|c|c|c|c|c|c|}
\hline \multirow{2}{*}{\multicolumn{3}{|c|}{ fabric }} & \multicolumn{3}{|c|}{$\mathbf{1}^{\text {st }}$ order and kinetics } & \multicolumn{3}{|c|}{$2^{\text {nd }}$ order and kinetics } \\
\hline & & & & & $\left(\mathrm{min}^{-1}\right)$ & & & $\left(\mathrm{g} \mathrm{mg}^{-1} \mathrm{~min}^{-1}\right)$ \\
\hline \multirow{2}{*}{ Wool } & MW & 5436.0036 & 0.83464 & 3113.5224 & 0.14397 & 0.9976 & 5749.93531 & $6.30 \times 10^{-5}$ \\
\hline & WB & 3357.3206 & 0.98906 & 7526.7603 & 0.04712 & 0.9917 & 4199.70434 & $6.12 \times 10^{-6}$ \\
\hline \multirow{2}{*}{ Silk } & MW & 3579.0578 & 0.93332 & 2718.7568 & 0.13252 & 0.9978 & 3813.76617 & $7.83 \times 10^{-5}$ \\
\hline & WB & 3044.2391 & 0.98005 & 3970.1533 & 0.04022 & 0.9965 & 3416.30397 & $1.45 \times 10^{-5}$ \\
\hline \multirow{2}{*}{$\begin{array}{l}\text { Wool/ } \\
\text { poly- } \\
\text { ester }\end{array}$} & MW & 3037.8839 & 0.94711 & 1278.9312 & 0.11528 & 0.9994 & 3128.92093 & $2.10 \times 10^{-4}$ \\
\hline & WB & 2700.4536 & 0.99388 & 4238.9887 & 0.04194 & 0.9957 & 3183.45622 & $1.13 \times 10^{-5}$ \\
\hline
\end{tabular}

that the binding interactions between the fabric surface and the dye molecules are not entirely physical, and at least in some regions chemical interactions between the dye molecules and the functional groups present on the fabric do occur, leading to the formation of temporary chemical bonds between them. The various constants obtained from the fit are given in Table 8.

\section{Freundlich isotherm}

It is well known that the Langmuir isotherm is based on the presence of a homogeneous absorbing surface and the independence of the absorption sites. However, the Freundlich isotherm empirically describes absorption on a heterogeneous surface where the most suitable sites are first occupied by the adsorbate dye molecules and the absorption enthalpy gradually changes with the extent of absorption.

In our case, the absorbent is fabric surface, whose surface is evidently heterogeneous with different types of functional groups attached. For this purpose, the Freundlich isotherm becomes appropriate for the description of absorption in this study, (Fig.7 and Table 9).

\section{Kinetic of dye uptake}

Half dyeing time $\left(t_{1 / 2} \mathrm{~min}\right)$ :

The half dyeing time $\left(\mathrm{t}_{1 / 2}\right)$, is the time that required for the fabric to absorb half of the dye amount that taken at equilibrium. The values of $\left(t_{1 / 2}\right)$ of dyeing are clearly short for those samples dyed with MW irradiation in comparison with those dyed with WB heating (Table 10).

Standard affinity of dyeing $\left(-\Delta \mu^{\circ}\right)$ :

Generally, the dyeing equilibrium data are reported as the standard of dyeing affinity $\left(-\Delta \mu^{\circ}\right)$. From the data listed in Table 10, it can be detected that the standard affinity of wool, silk and wool/polyester fabrics is lower when

TABLE 9. Langmuir and Freundlich isotherm.

\begin{tabular}{cccccccc}
\hline \multirow{2}{*}{ Fabric } & & \multicolumn{3}{c}{ Langmuir isotherm } & \multicolumn{2}{c}{ Freundlich isotherm } \\
\cline { 3 - 7 } & & $\mathbf{K}_{\mathbf{l}}(\mathbf{L} / \mathbf{g})$ & $\mathbf{R}^{2}$ & $\mathbf{Q}_{\max }(\mathbf{m g} / \mathbf{L})$ & $\mathbf{K}_{\mathbf{f}}(\mathbf{L} / \mathbf{g})$ & $\mathbf{R}^{2}$ & $\mathbf{1} / \mathbf{n}$ \\
\hline \multirow{2}{*}{ Wool } & MW & $4.66 \times 10^{-5}$ & 0.97839 & $8.3 \times 10^{3}$ & 19.83762 & 0.99643 & 0.53144 \\
& WB & $4.08 \times 10^{-5}$ & 0.97942 & $5.36 \times 10^{3}$ & 6.337916 & 0.99549 & 0.59409 \\
\multirow{2}{*}{ Silk } & MW & $5.25 \times 10^{-5}$ & 0.94407 & $5.79 \times 10^{3}$ & 15.60482 & 0.99079 & 0.52471 \\
\multirow{2}{*}{$\begin{array}{c}\text { Wool/ } \\
\text { Polyester }\end{array}$} & WB & $2.23 \times 10^{-5}$ & 0.96364 & $5.34 \times 10^{3}$ & 5.164715 & 0.99577 & 0.58877 \\
\hline
\end{tabular}


apply MW irradiation than WB heating. This is another mark for the enhancement effect of MW irradiation which leads to increase the affinity of safflower dye toward fabrics in comparison with WB heating.

\section{Fastness properties}

Fastness properties of the MW and WB dyed fabrics with safflower dyeing materials are listed in Table 11. The data indicate fair to good fastness properties of the dyed samples using WB heating

TABLE 10. Half dyeing time $\left(t_{1 / 2}\right)$, partition coefficient $(k p)$ and Dye affinity $\left(-\Delta \mu^{\circ}\right)$.

\begin{tabular}{|c|c|c|c|c|c|c|}
\hline \multirow{2}{*}{ Kinetic analysis } & \multicolumn{2}{|c|}{ Wool } & \multicolumn{2}{c|}{ Silk } & \multicolumn{2}{c|}{ Wool/polyester } \\
\cline { 2 - 7 } & MW & WB & MW & WB & MW & WB \\
\hline$\left(t_{1 / 2}\right), \min$ & 7.5 & 60 & 15 & 60 & 15 & 60 \\
\hline $\mathrm{Kp}$ & 0.1476 & 0.083114 & 1.066046 & 0.060838 & 0.06204 & 0.061826 \\
\hline$-\Delta \mu^{\circ}(\mathrm{J} / \mathrm{mol})$ & -5620.41 & -7292.35 & -5621.88 & -7277.03 & -8149.61 & -8159.78 \\
\hline
\end{tabular}

TABLE 11. Fastness Properties of dyed wool, silk and wool/ polyester fabrics with simultaneous safflower yellow dyeing materials using different heating techniques

\begin{tabular}{|c|c|c|c|c|c|c|c|c|c|c|}
\hline \multirow[b]{3}{*}{ Dyed fabrics } & \multirow{3}{*}{$\begin{array}{l}\text { Heating } \\
\text { methods }\end{array}$} & \multicolumn{2}{|c|}{ Washing } & \multicolumn{4}{|c|}{ Perspiration } & \multicolumn{2}{|c|}{ Rubbing } & \multirow{3}{*}{ Light } \\
\hline & & \multirow{2}{*}{ Alt } & \multirow{2}{*}{ St. } & \multicolumn{2}{|c|}{ Acidic } & \multicolumn{2}{|c|}{ Alkaline } & \multirow{2}{*}{ Dry } & \multirow{2}{*}{ Wet } & \\
\hline & & & & Alt & St. & Alt & St. & & & \\
\hline \multirow{2}{*}{ Wool } & MW & 5 & 5 & 5 & 5 & 5 & 5 & 5 & 5 & $6-7$ \\
\hline & WB & 4 & 4 & $4-5$ & $4-5$ & 4 & 4 & 3 & $2-3$ & 5 \\
\hline \multirow{2}{*}{ Silk } & MW & $4-5$ & 5 & 5 & $4-5$ & $4-5$ & 5 & 5 & $4-5$ & 7 \\
\hline & WB & $4-5$ & $4-5$ & $4-5$ & $4-5$ & $4-5$ & $4-5$ & $4-5$ & $4-5$ & $5-6$ \\
\hline \multirow{2}{*}{ Wool/polyester } & MW & 5 & 5 & 5 & 5 & 5 & 5 & 5 & 5 & $6-7$ \\
\hline & WB & 4 & 3 & 3 & 3 & 3 & 3 & $2-3$ & 2 & $4-5$ \\
\hline
\end{tabular}

Dyeing condition: $\mathrm{MW}$ : dye con. $4 \mathrm{~g} / 100 \mathrm{ml}, \mathrm{pH} 4$, dyeing temp. $60^{\circ} \mathrm{C}$ for wool and silk, $40^{\circ} \mathrm{C}$ for blend, dyeing time $10 \mathrm{~min}$ for wool, $15 \mathrm{~min}$ for silk, $20 \mathrm{~min}$ for blend. WB: dye con. $5 \mathrm{~g} / 100 \mathrm{ml}, \mathrm{pH} \mathrm{4}$, dyeing time $120 \mathrm{~min}$ at $100^{\circ} \mathrm{C}$ for all fabrics

while when using MW irradiation showed very good to excellent, this is due to MW irradiation effect.

\section{Conclusion}

Microwave irradiation proved effectiveness in the simultaneous dye extraction and dye-uptake of wool, silk, as well as, wool/polyester blend fabrics with safflower yellow dyeing materials. This leads to saving the processing time and energy and offers better environmental impact as it helps much dye-uptake and enhancement dye affinity. The kinetics of dyeing wool, silk and wool/polyester using safflower dyeing materials extracted simultaneously by different heating technique was analzed by monitoring UV-Vis absorption spectra of the reaction solution. Increasing dyeing time led to fast dyeing rate during the dyeing processes on using both heating techniques. All dye molecules were adsorbed onto fabrics even though different dyeing times. The fabrics dyeing with safflower dye included two stages, fast initial stage and slow second stage. The dyeing stage followed the pseudo-second-order kinetic model and the Freundlich isotherm becomes appropriate for the description of absorption in this study. The fastness properties ranged from fair to good when using untraditional heating while it ranged from very good to excellent when using microwave irradiation

\section{References}

1. Gereffi, G. Outsourcing and changing patterns of international competition in the apparel commodity chain. in Responding to Globalization: Societies, Groups and 
Individuals Conference, Boulder, Colorado. (2002).

2. Ghaly, A., et al., Production, characterization and treatment of textile effluents: a critical review. J Chem Eng Process Technol, 5(1), 1-19 (2014).

3. Keane, J. and D.W. te Velde, The role of textile and clothing industries in growth and development strategies. Overseas Development Institute, 7 (2008).

4. Samanta, A.K. and P. Agarwal, Application of natural dyes on textiles (2009).

5. Bechtold, T. and R. Mussak, Natural dyeingsquinoid, naphthoquinoid and anthraquinoid dyes. Handbook of Natural Dyeings: p. 151182 (2009).

6. Vankar, P.S., Handbook on Natural Dyes for Industrial Applications: National Institute of Industrial Re (2007).

7. An, K. and J. Kim, A study of the dyeability and physical properties of mordanted and finished fabrics dyed with natural dye of safflower. J. Kor. Soc. Dyers \& Finishers, 13, 23-31 (2001).

8. Shin, Y.-S., K.-H. Son, and D.-I. Yoo, Dyeing properties and color of silk fabrics dyed with safflower yellow dye. Journal of the Korean Society of Clothing and Textiles, 32(6), 928934 (2008).

9. Kanehira, T. and K. Saito, Stability of carthamin and safflor yellow $\mathrm{B}$ on silk powders under continuous irradiation of fluorescent or UV-C light. LWT-Food Science and Technology, 34(2), p. 55-59 (2001).

10. Nam, S.W., I.M. Chung, and I.H. Kim, Dyeing of Cotton Fabric with Natural Dye (I) Safflower. Textile Coloration and Finishing, 7(2), 47-54 (1995).

11. Wee, A., et al., Color accuracy of commercial digital cameras for use in dentistry. The Journal of Prosthetic Dentistry, 97(3), 178 (2007).

12. El-Shemy, N., et al., Synthesis and Applications of Nano Binder Based on Plant Oils. Journal of Natural Fibers, 14(1), 10-25 (2017).
13. Ho, Y.-S. and G. McKay, The kinetics of sorption of divalent metal ions onto sphagnum moss peat. Water Research, 34(3), 735-742 (2000).

14. Ho, Y.-S. and G. McKay, Pseudo-second order model for sorption processes. Process Biochemistry, 34(5), 451-465 (1999).

15. Freundlich, H., Über die adsorption in lösungen. Zeitschrift für physikalische Chemie, 57(1), 385-470 (1907).

16. Lewis, D., A. Renfrew, and A. Siddique, The synthesis and application of a new reactive dye based on disulfide-bis-ethylsulfone. Dyes and Pigments, 47(1-2), 151-167 (2000).

17. Weale, R., Color in Business, Science and Industry. The British journal of ophthalmology, 60(3), 232 (1976).

18. Kissa, E., Quantitative Determination of Dyes in Textile Fibers: Part II: Nonionic Dyes in Polyester, Polyamide Acrylic, Acetate, and Cellulosic Substrates. Textile Research Journal, 45(4), 290-295 (1975).

19. El-Shemy, N., N. El-Hawary, and H. ElSayed, Basic and Reactive-Dyeable Polyester Fabrics Using Lipase Enzymes. J Chem Eng Process Technol,7, 271 (2016).

20. Sun, S.-S. and R.-C. Tang, Adsorption and UV protection properties of the extract from honeysuckle onto wool. Industrial \& Engineering Chemistry Research, 50(8), 4217-4224 (2011).

21. Chen, C., et al. Adsorption Kinetics of Reactive Dyes on Silk with Octyl Butyl Dimethyl Ammonium Bromide as Accelerant. in Advanced materials research. Trans Tech Publ (2012).

22. Sribenja, S. and S. Saikrasun, Adsorption behavior and kinetics of lac dyeing on poly (ethyleneimine)-treated bamboo fibers. Fibers and Polymers, 16(11), 2391-2400 (2015).

(Received 13/9/2018; accepted 18/9/2018) 


\title{
تطوير وتحسين عملية استخر اج غير تقليدية للصباغة الصفراء من بتلات العصفر كصباغة طبيعية
}

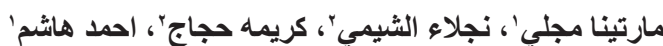

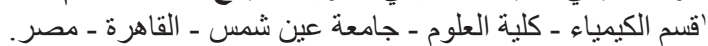 \\ rثعبة الصناعات النسيجيه ـ المركز القومي للبحوث ـ القاهرة ـ مصر.
}

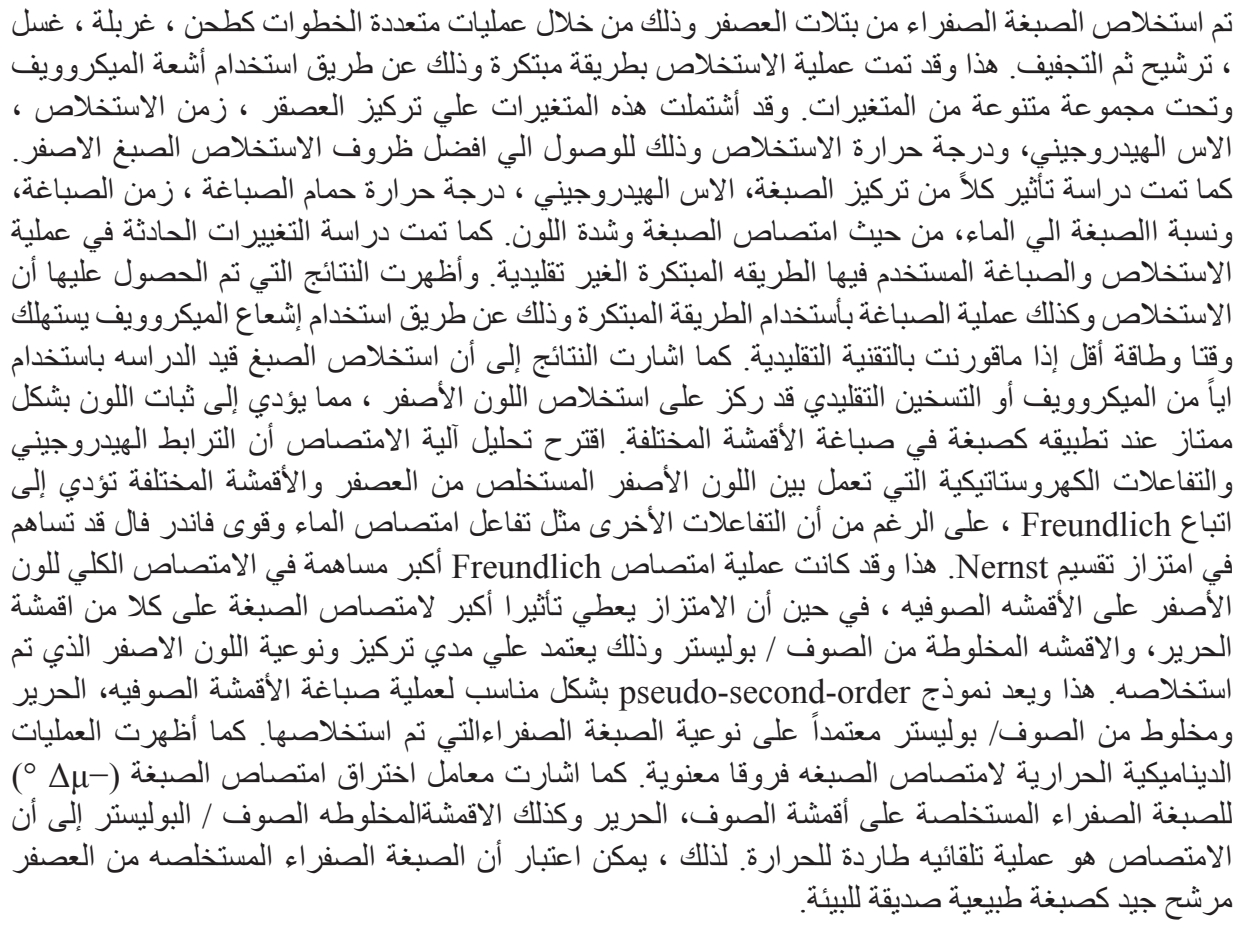

